\title{
Depletion of $E$. coli in permeable pavement mineral aggregate storage and reuse systems
}

\author{
B. R. Myers, S. Beecham, J. A. van Leeuwen and A. Keegan
}

\begin{abstract}
Permeable pavement reservoirs provide an important opportunity for the harvesting and storage of stormwater for reuse. This research aims to determine whether storage in dolomite, calcite and quartzite mineral aggregates in the base course of a permeable pavement impacts on the survival of the pathogen indicator organism Escherichia coli (E. coli) in storage. The reasons for depletion were also investigated. Twelve model permeable pavement storage reservoirs were filled, in triplicate, with dolomite, calcite and quartzite. Three reservoirs contained no aggregate. After filling with pathogen spiked rainwater, the concentration of $E$. coli was examined for 22 days in the reservoirs. The reservoirs were then agitated to determine if there was $E$. coli present which was not in aqueous suspension. The results of the experiments show that there is no significant difference in the depletion of $E$. coli found in reservoirs without aggregate, and those filled with dolomite or calcite. The rate of depletion was found to be significantly lower in the quartzite filled reservoirs. Agitation of the reservoirs yielded increases in the aqueous concentration of $E$. coli in all reservoir types, suggesting that the bacteria are adhering to the surface of the mineral aggregate and to the reservoir walls.

Key words $\mid$ E. coli, permeable pavement base course, stormwater reuse, water sensitive urban design (WSUD)
\end{abstract}

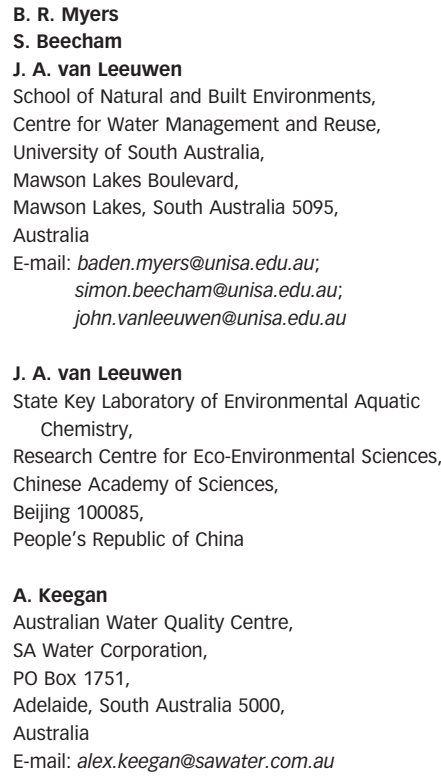

\section{INTRODUCTION}

Problems associated with urbanisation and its effect on the quantity and quality of stormwater runoff are well documented (Wong 2005). Permeable pavements provide a unique opportunity to infiltrate stormwater on site without compromising the above lying land use, particularly where the ability to withstand pedestrian and vehicular traffic is required (Pezzaniti et al. 2009). As well as infiltrating stormwater for temporary storage, permeable pavements can also be used to retain stormwater for reuse (Pratt 1999). One way to achieve this is to enclose the structurally supportive base course of a permeable pavement reservoir structure in an impermeable membrane, effectively making it an underground storage system as shown in Figure 1.
Previous research on microbial activity in permeable pavements has shown that the base course of a permeable pavement can develop and maintain a diverse microbial community. Pratt et al. (I999) report on a study over a period of three years which showed that a microbial community can sufficiently degrade oil pollution in model permeable pavement reservoirs under idealised conditions. Coupe et al. (2003) detail the composition of microbial communities in model permeable pavement reservoirs for the biodegradation of oils and grease. They showed that communities are capable of developing without dosing with commercially sourced oil-degrading bacteria. No significant difference was found between the levels of microbial activity in reservoirs dosed with a commercial oil-degrading 


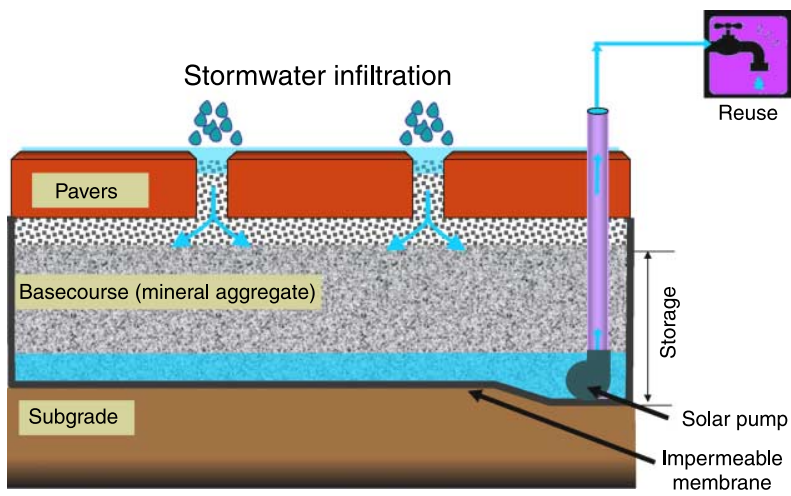

Figure $\mathbf{1}$ | Permeable pavement system with water reuse capability (adapted from Beecham \& Myers 2007)

microbial community and in reservoirs which had developed an indigenous microbial community. The authors also concluded that, as well as protozoa, fungi and bacteria both play a vital role in the degradation of oil products in permeable pavement reservoirs.

While there has been research into the capacity of permeable pavements to act as in situ bioreactors, there has been little research into the fate of pathogenic organisms in a permeable pavement reservoir. There is also very little information on the effect of permeable pavement base course media on water quality in long-term storage. Research has been undertaken on other infiltration systems to explore the removal of microorganisms. Hijnen et al. (2005) examined the ability of both a fine-grained sand and a gravelly soil (where $25 \%$ of particles were larger than $2 \mathrm{~mm}$ ) to retain microorganisms from spiked water using continuous flow experiments. They found that straining played a significant but variable role in the removal of $E$. coli. In the system proposed in Figure 1, however, there is no continuous through-flow as water is retained and stored in the mineral aggregate base course by the impermeable membrane.

The aim of this research was to investigate the effects over time of several types of base course aggregate material, specifically dolomite, calcite and quartzite, on the concentration of the bacterial pathogen indicator Escherichia coli (E. coli) in water stored in permeable pavements with an impermeable lining. A further aim was to investigate whether bacteria are present in the reservoir other than in the aqueous suspension, i.e. attached to the aggregate materials.

\section{MATERIALS AND METHODS}

\section{Experimental reservoirs}

The model reservoirs consisted of 12 polyvinylchloride (PVC) columns, $700 \mathrm{~mm}$ in length and $90 \mathrm{~mm}$ in internal diameter. PVC was selected to prevent light penetration into the column. The columns were identical in structure, with a sample port located $50 \mathrm{~mm}$ from the base of the reservoir, and an overflow tap $600 \mathrm{~mm}$ from the base of the reservoir to ensure each reservoir is filled to a height of $600 \mathrm{~mm}$. Three model reservoirs were filled with dolomite aggregate, three were filled with calcite aggregate, and three were filled with quartzite aggregate, each to a height of $650 \mathrm{~mm}$. Three model reservoirs were left empty of stone and served as control reservoirs.

\section{Preparation of aggregate}

The dolomite, calcite and quartzite aggregates were each sampled from stockpiles of coarse graded $20 \mathrm{~mm}$ aggregates sourced locally. Three equal volumes of each aggregate type were removed from stockpiles and washed over a $1.18 \mathrm{~mm}$ sieve until no further sediment washoff was observed. Each sample was then placed into an oven and held at $102^{\circ} \mathrm{C}$ for $24 \mathrm{~h}$. The dry mass of each aggregate sample was determined using calibrated scales before being packed into the experimental columns.

\section{Preparation of $E$. coli spiked rainwater}

Escherichia coli (ATCC 11775) was acquired from stock maintained at the Australian Water Quality Centre, Adelaide. Freshly grown colonies of this E. coli were maintained on blood agar for a maximum of one week until the beginning of the experiment. E. coli for experimental use was inoculated the day prior to starting the experiment. A colony of E. coli was cultured in $100 \mathrm{~mL}$ tryptone soy broth (TSB) (Oxoid, Australia) and incubated overnight at $35^{\circ} \mathrm{C}$ on a shaking platform at $150 \mathrm{rpm}$, to produce a stock of $E$. coli with approximately $1 \times 10^{9} \mathrm{cfu} / \mathrm{mL}$. This was washed in a phosphate buffer solution (PBS), containing $3.125 \times 10^{-4} \mathrm{M} \mathrm{KH}_{2} \mathrm{PO}_{4}$ and $2 \times 10^{-3} \mathrm{M} \mathrm{MgCl}_{2}$, to minimise additional nutrient dosing 
in the spiked rainwater. The culture was centrifuged at $1,800 \mathrm{~g}$, the supernatant was decanted and the pellet washed in $100 \mathrm{~mL}$ PBS. This was repeated three times to minimise nutrient carry-over.

A $25 \mathrm{~L}$ polypropylene container was filled with rainwater from a rainwater tank connected to the roof of a domestic household in Adelaide, Australia. This rainwater sample was tested for the presence of E. coli, showing no viable, measurable community. The container was then dosed with $25 \mathrm{~mL}$ of the prepared E. coli suspension. The spiked rainwater was mixed by agitation.

\section{Experimental design}

Following the spiking of rainwater with E. coli, a $600 \mathrm{~mL}$ sample was taken into a sterile PET bottle for analysis. Spiked rainwater was poured into the top of each of the 12 model reservoirs to a height of $600 \mathrm{~mm}$. 60 seconds after each column was filled, samples were removed from each reservoir to determine concentrations of $E$. coli and UV absorbance at time $t=0$. Samples were removed at 24- and 48-h intervals over the following nine days, and the final sample was removed at 22 days. The experiment was undertaken indoors to minimise the influence of varying temperature on microbial activity. The temperature was maintained at $22^{\circ} \mathrm{C}$ throughout the experimental period.

Samples were taken from the lower tap of each reservoir and placed into sterile $30 \mathrm{~mL}$ polystyrene containers. Each sample was taken by removing a $30 \mathrm{~mL}$ first flush from the reservoir which was discarded before sampling one $30 \mathrm{~mL}$ volume for microbial investigation, and a further $30 \mathrm{~mL}$ volume for analysis of UV absorbance at $254 \mathrm{~nm}$. Water quality analysis was undertaken on the pathogen spiked rainwater immediately after mixing, and on samples from the column reservoirs on day one and day nine using a $600 \mathrm{~mL}$ sample taken from each reservoir.

At the conclusion of the experiment, the reservoirs were agitated in an attempt to disturb any bacteria that may have been weakly bound on the column and aggregate media surfaces. This agitation consisted of 10 consecutive full inversions of the model reservoirs at a rate of one inversion every 10 seconds. Samples were withdrawn from the sample points immediately before and after this agitation.

\section{Water quality analysis}

All enumeration of $E$. coli in these experiments was conducted by determination of colony forming units (cfu) on plates with selective media (Differential Faecal Coliform agar, Australian Water Quality Centre, Adelaide). For each $30 \mathrm{~mL}$ sample, $100 \mu \mathrm{L}$ subsamples were plated in triplicate. Samples were diluted in phosphate buffer solution to achieve reasonable colony counts for counting (between 10 and $200 \mathrm{cfu}$ per plate). The results for each sample were recorded as the mean value of the three sub-samples. UV spectrophotometry was undertaken using a spectrophotometer (Hitachi $\mathrm{U}-3200)$. Both $\mathrm{pH}$ and conductivity were measured using an electronic meter (TPS FL-90). The $\mathrm{pH}$ and conductivity readings were calibrated daily using standard solutions (pH 4 and $\mathrm{pH} 6.88 ; 2,760 \mu \mathrm{S} / \mathrm{cm}$, TPS Inc.).

\section{Data analysis}

All data of E. coli counts were reported as the mean of three subsamples taken from each reservoir. The method, based on Chick's law, outlined by El-Shaarawi \& Pipes (I982) was applied to calculate a first order rate of bacterial depletion $k_{\mathrm{d}}$. Briefly, this was based on the following relationship:

$\log _{e} \frac{N_{t}}{N_{0}}=-K_{\mathrm{d}} t$

where $N_{t}$ represents the concentration $(\mathrm{cfu} / \mathrm{mL})$ at time $t$ (days), $N_{0}$ represents the concentration at day 0 and the decay constant $k$ represents the die-off rate $\left(\log _{10}\right.$ reduction per day). By plotting a graph of $N_{t} / N_{0}$ against $t$, and using linear regression analysis with a forced intercept through $y=1$, the value of $k_{\mathrm{d}}$ was determined. This methodology, based on first order decay, corresponds with similar studies of bacterial depletion in water (Van der Steen et al. 2000) and soil environments (Jamieson et al. 2005).

Secondly, the one log removal time $T_{90}$ was calculated in accordance with procedures outlined by Gordon \& Toze (2003). The $T_{90}$ value at each sampling point was calculated using the mean concentration found in each reservoir and the following relationship:

$T_{90}=\frac{-t}{\log _{10} \frac{N_{t}}{N_{0}}}$

The values of $T_{90}$ were then averaged over the sampling period to acquire a mean $T_{90}$ and standard deviation. 
The statistical significance of the results was determined by comparing the values of $k_{\mathrm{d}}$ and $T_{90}$ for repeat reservoir groups using an ANOVA. All statistical analysis was undertaken using a computer package (Prism 4.0 for Windows, Graphpad Software Inc.).

\section{RESULTS AND DISCUSSION}

\section{Nutrient levels in the reservoirs}

The level of UV absorbance in the spiked rainwater was 0.017 , and this showed little change immediately after being added to the control and dolomite reservoirs. However, there was a notable increase in the level of UV absorbance following the addition of spiked rainwater to calcite, and a reduction in the level of UV absorbance after the solution was added to the quartzite filled reservoirs. The change in the level of UV absorbance after the solution was added to the reservoirs is shown in Figure 2. In Figure $2, t=0$ represents the value of UV absorbance immediately after the spiked rainwater was added to the reservoirs. Throughout the first nine days, the level of UV absorbance typically fell by $15-18 \%$ in the control reservoirs. In the dolomite, calcite and quartzite reservoirs, the reduction in UV absorbance was 56-58\%, 17-29\% and 15-37\%, respectively, for this period. Figure 2 shows that the calcite reservoirs had much higher levels of UV absorbance compared to the control, dolomite and quartzite reservoirs. This indicated that UV absorbing compounds were

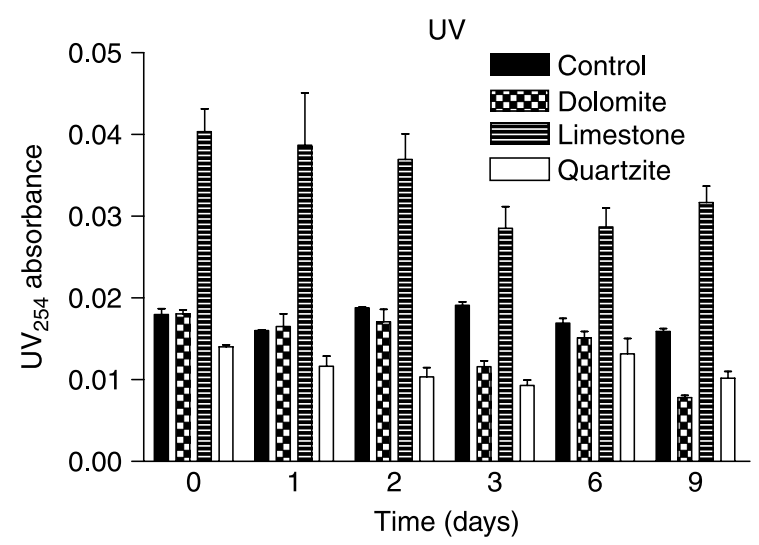

Figure 2 Change in UV absorbance over the first nine days of the experiment. All results are shown as the mean \pm SD of each value based on the three measurements from repeat reservoirs. associated with the calcite used in this research, which leached into solution. It can be concluded that these compounds were non-volatile in nature, based on the aggregate preparation outlined previously. The removal of UV absorbing natural organic matter in aggregate filled reservoirs has been shown to occur in previous research on permeable pavement reservoirs (Myers et al. 2007). The reduction in UV absorbance may be attributed to biodegradation by developing biomass in the reservoir and sorption of UV absorbing matter to surfaces in the reservoir.

\section{Change in $\mathrm{pH}$ and conductivity}

The changes in $\mathrm{pH}$ and conductivity that were found to occur in the reservoirs over the first nine days of the experiment are shown in Figure 3. The most notable changes in $\mathrm{pH}$ and conductivity were measured in the dolomite and calcite filled reservoirs, where the mean $\mathrm{pH}$ increased from an initial value of 6.7 to 8.3 in the dolomite and 8.8 in the calcite filled reservoirs after nine days. The $\mathrm{pH}$ in the dolomite and calcite reservoirs increased after one day, with further increases after nine days. The $\mathrm{pH}$ remained comparatively stable in the quartzite reservoir. From the initial mean value of 6.7 , it was found to be 6.6 after nine days. The control reservoir showed a slight increase in $\mathrm{pH}$, increasing from 6.7 to 7.4 over the first day and remaining at this level on day nine.

Similar responses were found for the level of conductivity. The level of conductivity in the control reservoir showed a 10\% increase after nine days. The quartzite reservoirs showed a 73\% increase after one day and 114\% increase after nine days. The dolomite and control reservoirs showed the largest increase in conductivity. Dolomite and calcite increased by $167 \%$ and $186 \%$ after one day and $188 \%$ and $293 \%$ after nine days, respectively.

The increases in $\mathrm{pH}$ and conductivity in the dolomite and calcite filled reservoirs may be attributable to the dissolution of calcium and magnesium carbonates at the mineral surfaces. This process is a well noted phenomenon in aqueous environments, resulting in a number of dissolved and semi-dissolved salts including calcium, magnesium, and carbonate constituents as outlined by Chou et al. (I989). Research into the impact of this dissolution on the $\mathrm{pH}$ and conductivity of stored water by repeatedly filling and 

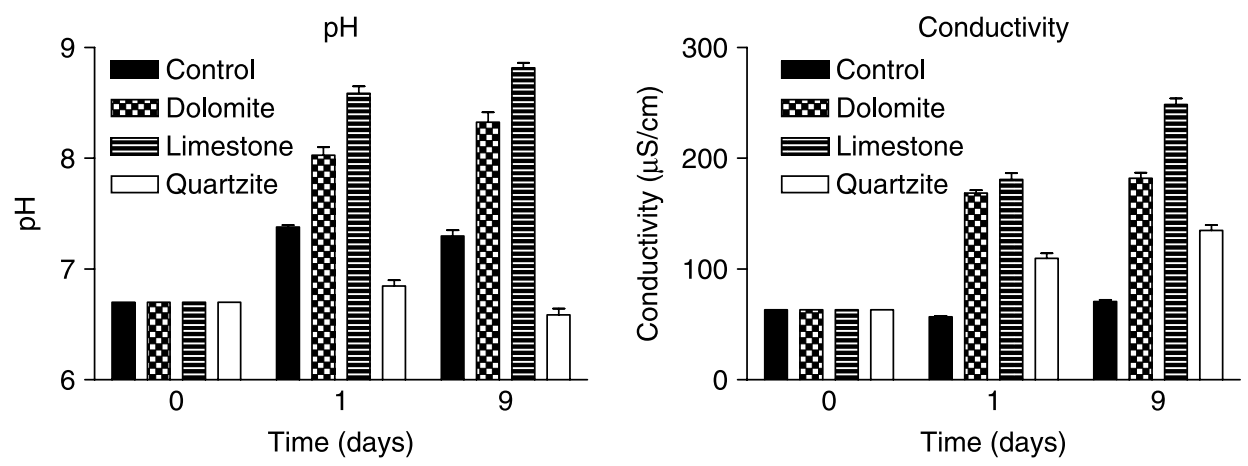

Figure 3 | Change in pH and conductivity with time. All data is based on the mean of three reservoirs for the control and dolomite, calcite and quartzite filled reservoirs.

emptying reservoirs has shown that the effects of dolomite on water quality continue with repeated additions of water, whilst the effect of quartzite tends to diminish (Myers et al. 2009).

\section{Depletion of $E$. coli in the reservoirs}

The overall changes in the concentration of $E$. coli over the experimental period are shown in Figure 4. Results are shown as the individual mean reading for each sample point in each reservoir.

Using the data shown in Figure 4, the mean values of $k_{\mathrm{d}}$ and $T_{90}$ are shown in Table 1 for each reservoir type. The values of $k_{\mathrm{d}}$ and $T_{90}$ are based on the first nine days of the experimental data where the data for calculation is sufficiently linear. Goodness of fit (as indicated by the coefficient of determination $\left(r^{2}\right)$ is based on a linear plot in accordance with Chick's law outlined previously, and is
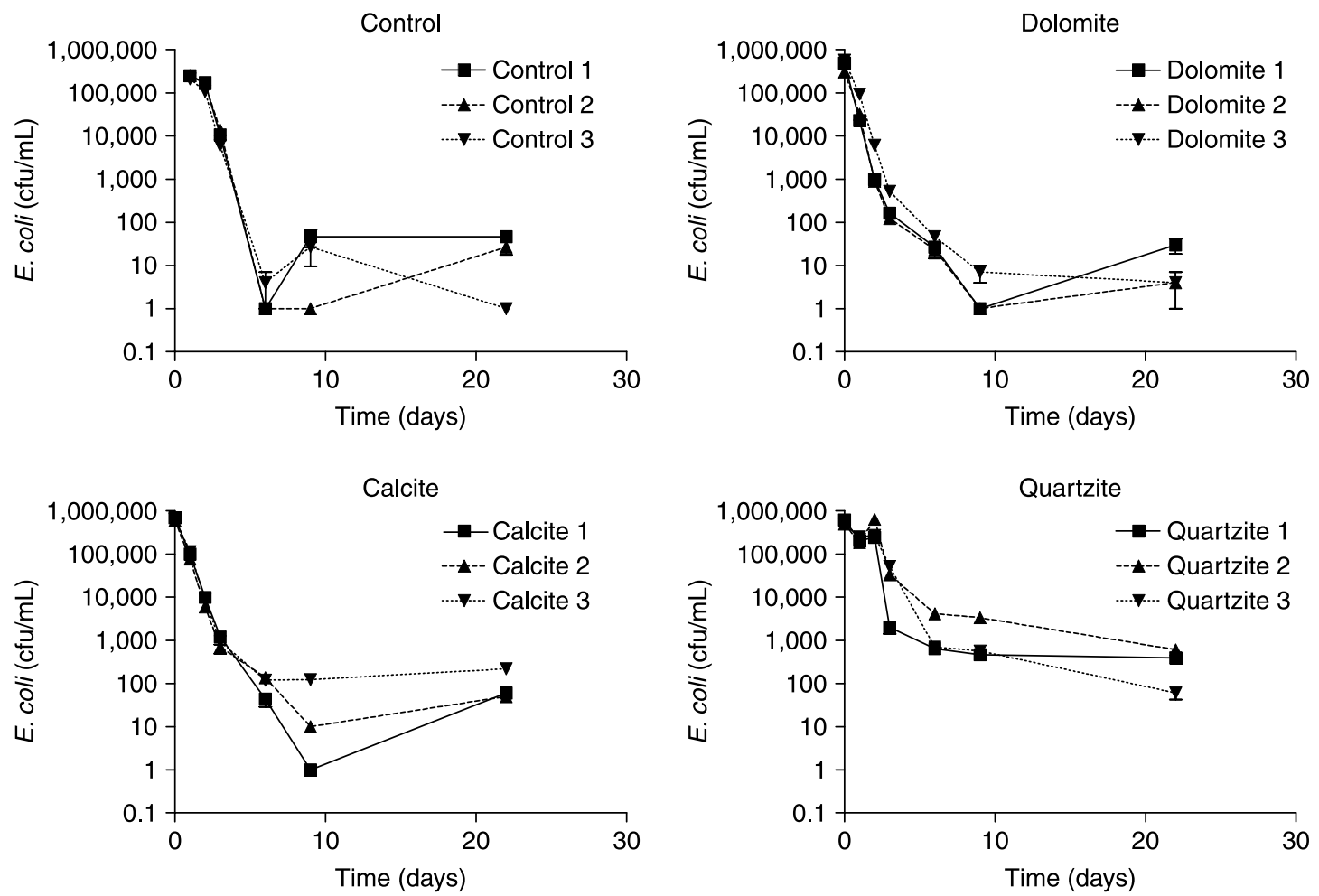

Figure 4 | Change in concentration of $E$. coli (cfu/mL) in the pathogen spiked reservoirs with time (days) in the Control, Dolomite, Calcite and Quartzite reservoirs. All values are expressed as a mean with error bars shown. 
Table 1 Mean values of $k_{\mathrm{d}}$ and $T_{90}$ for the depletion of $E$. coli

\begin{tabular}{lllll} 
& \multicolumn{2}{l}{$\begin{array}{l}\text { Mean rate of depletion } \\
\left(\mathbf{l o g}_{\mathbf{1 0}} \text { per day) }\right.\end{array}$} & & \multicolumn{2}{l}{ Removal time (days) } \\
& $\boldsymbol{k}_{\mathbf{d}}$ & $\boldsymbol{r}^{\mathbf{2}}$ & $\boldsymbol{T}_{\mathbf{9 0}}$ & SD \\
\hline Control & -1.56 & 0.83 & 1.63 & 0.50 \\
Dolomite & -1.56 & 0.83 & 1.18 & 0.37 \\
Calcite & -1.39 & 0.84 & 1.37 & 0.30 \\
Quartzite & -0.81 & 0.86 & 3.32 & 1.64 \\
\hline
\end{tabular}

consistent across all reservoirs for the first nine days of the experiment. There was no significant difference found between the values of $k_{\mathrm{d}}$ in the control reservoirs compared to the values of $k_{\mathrm{d}}$ in either the dolomite or calcite filled reservoirs $(p>0.05)$. However the value of $k_{\mathrm{d}}$ in the control, dolomite and calcite filled reservoirs was found to be significantly higher than the value of $k_{\mathrm{d}}$ in the quartzite filled reservoirs ( $p<0.05$ in each case).

The level of $\mathrm{pH}$ may be a factor in the different depletion rates of E. coli. Bowie et al. (1985) notes that E. coli is generally found to survive longer in lower $\mathrm{pH}$ solutions $(\mathrm{pH}<8)$ than in alkaline solutions. In this experiment, the $\mathrm{pH}$ increases to levels higher than 8 in the dolomite and calcite reservoirs, while the quartzite reservoirs have the lowest $\mathrm{pH}$. The control reservoirs all have a $\mathrm{pH}<8$ after nine days, which indicates there are other influencing factors, which are discussed below.

The higher levels of organic matter found in the calcite reservoirs shown in Figure 2, which may suggest a larger source of available nutrients, may have had an impact on the rate of $E$. coli depletion found in the calcite reservoirs.

\section{Disturbance of reservoirs}

After 22 days, a selection of the reservoirs were shaken to investigate whether bacteria are likely to be weakly attached to aggregates and walls of the reservoirs. The concentrations of $E$. coli in solution immediately prior to and immediately after disturbance are shown in Table 2. It was also observed that, despite washing aggregate media to remove fines prior to the addition of $E$. coli in the reservoirs as described previously, the samples taken immediately after shaking the aggregate filled reservoirs were discoloured with what appeared to be fine sediment.

\section{Fate of $E$. coli in permeable pavement reservoirs}

The results in Table 2 suggest that $E$. coli remained present in the reservoirs in a viable state other than in the aqueous suspension, i.e. attached to the aggregate and reservoir walls. The increases do indicate that die-off is not the only mechanism responsible for the observed reductions in pathogen concentration. From the list of factors affecting the concentration of coliform bacteria in aqueous environments provided by Bowie et al. (1985), it can be proposed that sedimentation and adsorption may also be responsible for the reduction in E. coli observed in this research. Kristian Stevik et al. (2004) reviewed literature on pathogen removal using filtration through porous media, and states that the two mechanisms responsible for the immobilisation of pathogens are straining and adsorption. As straining implies the physical blockage of bacteria, its effect can be assumed negligible in this present study due to the use of open graded aggregate with wide gaps. The increased concentration noted in Table 2 may therefore be attributable to the disturbance, sampling and plating of bacteria settled at the base of the reservoir and/or to bacteria that have adsorbed to the aggregate media and the reservoir walls.

The influence of sedimentation of $E$. coli has been investigated in previous studies on the depletion of faecal coliforms (Gannon et al. 199I). Like depletion in a water

Table 2 | Change in the concentration of $E$. coli in the reservoirs after disturbing the column content

\begin{tabular}{|c|c|c|c|c|}
\hline Reservoir & $\begin{array}{l}\text { Control } \\
(\text { cfu/mL, mean } \pm \text { SD) }\end{array}$ & $\begin{array}{l}\text { Dolomite } \\
\text { (cfu/mL, mean } \pm \text { SD) }\end{array}$ & $\begin{array}{l}\text { Calcite } \\
\text { (cfu/mL, mean } \pm \text { SD) }\end{array}$ & $\begin{array}{l}\text { Quartzite } \\
(\mathrm{cfu} / \mathrm{mL}, \text { mean } \pm \mathrm{SD})\end{array}$ \\
\hline Concentration $E$. coli before & $27 \pm 15$ & $3 \pm 6$ & $50 \pm 17$ & $607 \pm 172$ \\
\hline Concentration E. coli after & $127 \pm 46$ & $80 \pm 56$ & $253 \pm 99$ & $8,207 \pm 867$ \\
\hline Overall $\%$ increase & 375 & 2,300 & 407 & 1,253 \\
\hline Log increase & 0.68 & 1.38 & 0.70 & 1.13 \\
\hline
\end{tabular}


column, depletion of coliforms in the settled matter has been noted to display an exponential decay (Jamieson et al. 2005). Sedimentation occurs via the adsorption of bacteria to fine particles and subsequent settlement of those particles in the water. Although the aggregate material in this study was washed prior to the addition of $E$. coli, water samples taken from the reservoirs immediately after disturbance were discoloured with what appeared to be fine material, suggesting the potential for settlement to have occurred.

Adsorption of microorganisms to fine matter and aggregate surfaces is an important consideration in this research. Adsorption of different strains of E. coli to solid surfaces has been found to occur in several studies (Dunne 2002). Adsorption by microorganisms is a two-step process. The first step is a reversible form of adsorption caused primarily by electrostatic attraction, van der Waals forces and/or hydrophobicity. Bacteria attached in this manner can detach from the surface and return to an aqueous phase (Kristian Stevik et al. 2004). Dunne (2002) indicates that this primary form of adhesion is also encouraged because organic substances in solution will concentrate near a surface, and microorganisms will tend to congregate in nutrient-rich environs. The second step in adsorption is an irreversible adsorption and is said to occur when bacteria produce polymers forming bridges connecting bacteria to the surface. The occurrence of this second step cannot be suggested from the results of this research and is unlikely given previous research on biofilm formation by ATCC 11775 E. coli (Rivas et al. 2007), but the former, reversible form of adhesion is a possible explanation for the increase in $E$. coli numbers after the reservoirs were disturbed.

Scholl et al. (I990) investigated the effect of different minerals on the attachment of bacteria. They compared the extent of attachment by a type of bacteria (Lula D, an Arthrobacter species) to the surfaces of several minerals, including quartz and calcite. Their results showed that attachment was higher on limestone than clean quartz, and they suggest that the electrostatic interactions between bacteria and the mineral surface are responsible. It is known that bacteria tend to have a negative surface charge (Dunne 2002) and the ATCC 11775 E. coli used in these experiments is noted for a strongly negative surface charge (Rivas et al. 2007). The surface charge of material in this experiment, based on the $\mathrm{pH}$ at point of zero charge $\left(\mathrm{pH}_{\mathrm{zpc}}\right)$ of pure quartz, dolomite and calcite from literature is shown in Table 3. The constituents of the minerals in this experiment may differ from the materials used to quantify the point of zero charge in literature and are only used as indicator values.

The values of $\mathrm{pH}_{\mathrm{pzc}}$ in Table 3 indicate that under $\mathrm{pH}$ conditions at the beginning of the experiment ( $\mathrm{pH}$ 6.7) there was likely to have been a net electrostatic attraction between the negatively charged bacteria and the calcite and dolomite surfaces in the reservoirs. After one day, the $\mathrm{pH}$ values of water in the dolomite and calcite reservoirs (with mean values of 8 and 8.6, respectively) are likely to be nearer the point of zero charge.

The presence of electrostatic attraction does, however, fail to explain the depletion of $E$. coli in the control reservoir, where only PVC reservoir walls are available for adhesion. Furthermore, Stenstrom (I989) studies the attachment of bacteria to soil and finds that solution $\mathrm{pH}$ and the negative surface charge of bacteria had little effect on the extent of attachment of bacteria, finding that attachment is more a function of isolated points of positive charge on bacteria such as hydrophobic fimbriae on E. coli.

There are many implications from this study for the design and operation of permeable pavements for harvesting and fit-for-purpose reuse. In the event of contamination of the reservoir after infiltration of pathogen polluted waters, pathogens can be expected to die off in a manner that is partially dependent on the aggregate material used in the storage reservoir. The observed reductions in E. coli may be a result of die-off, as well as adsorption of the pathogens to materials in the reservoir. Further research is required to determine what mechanism is responsible for the removal of $E$. coli in a permeable pavement reservoir. Research should also be undertaken to determine whether the operation of a pump at the base of the reservoir can

Table 3 | Surface charge of minerals from literature

\begin{tabular}{|c|c|c|}
\hline Mineral & $\mathrm{pH}_{\mathrm{zpc}}$ & $\begin{array}{l}\text { Anticipated surface charge in this } \\
\text { experiment }\end{array}$ \\
\hline Dolomite & $8^{*}$ & Initially positive, then negative \\
\hline Calcite & $8-8.5^{\dagger}$ & Initially positive, then negative \\
\hline Quartz and silica & $2^{\dagger}$ & Positive \\
\hline
\end{tabular}

*Pokrovsky \& Schott (2001).

${ }^{\dagger}$ Stumm \& Morgan (1996). 
disturb pathogenic contaminants that are viable but are not in aqueous suspension in a permeable pavement reservoir, and to investigate the applicability of the survival rate of the $E$. coli found in laboratory reservoirs to that observed in field conditions.

\section{CONCLUSIONS}

This research has found that the use of mineral aggregates can have an effect on the depletion of the potentially pathogenic bacteria $E$. coli in mineral aggregate filled model reservoirs, and that this difference depends on the type of mineral aggregate used. Using rainwater spiked with $E$. coli in model reservoirs, there was no statistically significant difference found in the rate of depletion of $E$. coli in reservoirs without aggregate and reservoirs filled with dolomite and calcite aggregates. All reservoirs show that the rate of depletion was significantly slower in the presence of quartzite aggregate. Changes in the $\mathrm{pH}$, conductivity and UV absorbance of water in the reservoirs are not sufficient to explain the different depletion rates. Measurements of $E$. coli concentration before and after agitating the reservoirs suggest that, in all reservoirs, some $E$. coli are present in the reservoir other than in the aqueous suspension and it is suggested that these organisms are attached to the reservoir walls and aggregate surfaces.

\section{ACKNOWLEDGEMENTS}

The authors acknowledge the Microbiology Research and Development team at the SA Water Australian Water Quality Centre, Water Quality Research Australia (and previously the CRC for Water Quality and Treatment) for their generous support and assistance with this project.

\section{REFERENCES}

Beecham, S. \& Myers, B. 2007 Structural and design aspects of porous and permeable block pavement. J. Aust. Ceram. Soc. 43(1), 74-81.

Bowie, G. L., Mills, W. B., Porcella, D. B., Campbell, C. L., Pagenkopf, J. R., Rupp, G. L., Johnson, K. M., Chan, P. W. H. \& Gherini, S. A. 1985 Rates, Constants, and Kinetics
Formulations in Surface Water Quality Modeling, 2nd edition. United States Environmental Protection Agency, Athens, Georgia, USA.

Chou, L., Garrels, R. M. \& Wollast, R. I989 Comparative study of the kinetics and mechanisms of dissolution of carbonate minerals. Chem. Geol. 78(3-4), 269-282.

Coupe, S. J., Smith, H. G., Newman, A. P. \& Puehmeier, T. 2003 Biodegradation and microbial diversity within permeable pavements. Eur. J. Protistol. 39(4), 495-498.

Dunne, W. M., Jr 2002 Bacterial adhesion: seen any good biofilms lately? Clin. Microbiol. Rev. 15(2), 155-166.

El-Shaarawi, A. H. \& Pipes, W. O. I982 Enumeration and statistical inferences. In: El-Shaarawi, A. H. \& Pipes, W. O. (eds) Bacterial Indicators of Pollution. CRC Press Inc., Boca Raton, FL, Chapter 3.

Gannon, J., Tan, Y. H., Baveye, P. \& Alexander, M. I99i Effect of sodium chloride on transport of bacteria in a saturated aquifer material. Appl. Environ. Microbiol. 57(9), 2497-2501.

Gordon, C. \& Toze, S. 2003 Influence of groundwater characteristics on the survival of enteric viruses. J. Appl. Microbiol. 95(3), 536-544.

Hijnen, W. A. M., Brouwer-Hanzens, A. J., Charles, K. J. \& Medema, G. J. 2005 Transport of MS2 phage, Escherichia coli, Clostridium perfringens, Cryptosporidium parvum, and Giardia intestinalis in a gravel and a sandy soil. Environ. Sci. Technol. 39, 7860-7868.

Jamieson, R. C., Joy, D. M., Lee, H., Kostaschuk, R. \& Gordon, R. J. 2005 Resuspension of sediment-associated Escherichia coli in a natural stream. J. Environ. Qual. 34(2), 581-589.

Kristian Stevik, T., Kari, A., Ausland, G. \& Fredrik Hanssen, J. 2004 Retention and removal of pathogenic bacteria in wastewater percolating through porous media: a review. Water Res. 38(6), $1355-1367$.

Myers, B., Sagi, I., Van Leeuwen, J. \& Beecham, S. 2007 Water quality improvement by base course aggregate in a permeable pavement with underlying reservoir structure. Proceedings of 13th International Rainwater Catchment Systems Conference 5th International Water Sensitive Urban Design Conference, Sydney, Australia.

Myers, B., Van Leeuwen, J. \& Beecham, S. 2009 An experimental study on the long-term water quality impacts of gravel media in storage underlying permeable pavements. Proceedings of The 6th International Water Sensitive Urban Design Conference and Hydropolis \#3, Perth, Australia.

Pezzaniti, D., Beecham, S. \& Kandasamy, J. 2009 Influence of clogging on the effective life of permeable pavements. J. Water Manage. 162(3), 211-220.

Pokrovsky, O. S. \& Schott, J. 20or Kinetics and mechanism of dolomite dissolution in neutral to alkaline solutions revisited. Am. J. Sci. 301(7), 597-626.

Pratt, C. J. 1999 Use of permeable, reservoir pavement constructions for stormwater treatment and storage for re-use. Water Sci. Technol. 39(5), 145-151. 
Pratt, C. J., Newman, A. P. \& Bond, P. C. 1999 Mineral oil bio-degradation within a permeable pavement: long term observations. Water Sci. Technol. 39(2), $103-109$.

Rivas, L., Dykes, G. A. \& Fegan, N. 2007 A comparative study of biofilm formation by Shiga toxigenic Escherichia coli using epifluorescence microscopy on stainless steel and a microtitre plate method. J. Microbiol. Methods 69(1), $44-51$.

Scholl, M. A., Mills, A. L., Herman, J. S. \& Hornberger, G. M. I99o The influence of mineralogy and solution chemistry on the attachment of bacteria to representative aquifer materials. J. Contam. Hydrol. 6(4), 321-336.
Stenstrom, T. A. 1989 Bacterial hydrophobicity, an overall parameter for the measurement of adhesion potential to soil particles. Appl. Environ. Microbiol. 55(1), 142-147.

Stumm, W. \& Morgan, J. J. 1996 Aquatic Chemistry: Chemical Equilibria and Rates in Natural Waters, 3rd edition. John Wiley and Sons, New York.

Van der Steen, P., Brenner, A., Shabtai, Y. \& Oron, G. 2000 The effect of environmental conditions on faecal coliform decay in post-treatment of UASB reactor effluent. Water Sci. Technol. 42(10), 111-118.

Wong, T. H. F. 2005 Introduction. In: Wong, T. H. F. (ed.) Australian Runoff Quality-A Guide to Water Sensitive Urban Design. Engineers Australia, Australia. 